\title{
INDIRECT AND DIRECT EFFECTS IN A TROPICAL AGROECOSYSTEM: THE MAIZE-PEST-ANT SYSTEM IN NICARAGUA ${ }^{1}$
}

\author{
IVETTE PERFECTO \\ School of Natural Resources, University of Michigan, Ann Arbor, Michigan 48109 USA
}

\begin{abstract}
This study examines the direct and indirect effects of insecticides in maizepest-ant system in Nicaragua. Population levels of two herbivores, the fall armyworm, Spodoptera frugiperda J. E. Smith, and the corn leafhopper, Dalbulus maidis De Long, were monitored and compared among four insecticide treatments: (1) carbofuran, a systemic insecticide; (2) chlorpyrifos, a broad-spectrum insecticide; (3) a combination of carbofuran and chlorpyrifos; and (4) a control, where no insecticide was applied. Ant foraging activity also was monitored throughout the season for all four insecticide treatments. Predation of $S$. frugiperda pupae was estimated with relation to insecticide treatment and ant foraging activity.

Carbofuran reduced ant foraging activity and increased population levels of the fall armyworm. Ant predation was apparently responsible for a higher pupal removal rate in the plots with no insecticides. Chlorpyrifos significantly reduced ant foraging activity as well as densities of the fall armyworm, but it resulted in higher levels of the corn leafhopper. The results of this study are discussed in light of the possibility of developing integrated pest management programs in which ants may play an important role as agents of biological control. In such a case, ant susceptibility to chemical insecticides should be taken into consideration.
\end{abstract}

Key words: biological control; Dalbulus maidis; Ectatoma ruidum; foraging ants; indirect effects; insecticide; Nicaragua; pest resurgence; Pheidole radowszkoskii; Spodoptera frugiperda.

\section{INTRODUCTION}

Several ecologists have suggested that direct interactions among species may not be as important in structuring communities as indirect ones (Vandermeer et al. 1985, Miller and Kerfoot 1987, Pianka 1987). Indirect effects are particularly interesting because they are not easily anticipated by considering simple pairwise species interactions (Vandermeer et al. 1985). Although there are several theoretical models capable of predicting the dramatic but non-obvious effects of indirect interactions (Levins 1975, Vandermeer 1980, Shaffer 1981), experimental examinations of such effects are rare (Pianka 1987, Yodzis 1988).

One of the clearest examples of indirect interactions is that of pest resurgence due to the use of insecticide (Ripper 1956, Stern et al. 1959, van den Bosch and Stern 1962, Theiling and Croft 1988). Although one of the interesting components of this system is a nonbiological entity (insecticide), it nevertheless provides an excellent case study of how indirect effects can generate a completely unexpected result-higher levels of the pest when insecticides are applied. Insecticides may increase the abundance of pest insects because they kill the natural enemies of the pests. This phenomenon has been demonstrated with strong, yet circumstantial, evidence on a large scale involving years of pesticide ap-

\footnotetext{
${ }^{1}$ Manuscript received 8 May 1989; revised 31 January 1990; accepted 5 February 1990.
}

plications in the cotton agroecosystem in Central America (Swezey and Daxl 1983) and elsewhere (Huffaker 1971). However, it has not been shown that pests can resurge within a single field and in a single season as a result of the indirect effects of insecticides.

This paper presents the results of field experiments designed to determine whether an indirect effect caused by insecticide applications could be detected within a single planting season. The experiment was conducted in the maize (Zea mays) agroecosystem in the Pacific Coast of Nicaragua, and examined a potential indirect effect associated with two of the most commonly used insecticides in maize production, chlorpyrifos and carbofuran (Lorsban and Furadan, respectively). These insecticides are normally used to control two of the most abundant pests in maize: Spodoptera frugiperda J. E. Smith (Lepidoptera: Noctuidae), the fall armyworm, and Dalbulus maidis DeLong (Homoptera: Cicadellidae), the maize leafhopper.

\section{Natural history of the system}

The study was conducted at Las Mercedes Experimental Center in Managua, Nicaragua, where groundforaging ants (Hymenoptera: Formicidae) were the most obvious predators. Ants have frequently been used as biological control agents in the past (Clausen 1940, Adlung 1966, De Bach 1974, Finnegan 1975, Castiñeiras et al. 1982), and are regarded as one of the more important insect predators in undisturbed tropical en- 
TABLE 1. List of ant species on the experimental site before the application of treatments.

\begin{tabular}{lccc}
\hline \hline & No. baits & \multicolumn{2}{c}{ \% Foraging activity* } \\
\cline { 3 - 4 } \multicolumn{1}{c}{ Species } & $(N=64)$ & Mean & SE \\
\hline Pheidole radowszkoskii & 38 & 57.29 & 9.74 \\
Ectatomma ruidum & 17 & 19.27 & 5.88 \\
Conomyrma sp. & 9 & 11.46 & 5.32 \\
Solenopsis globularia & 6 & 8.85 & 4.06 \\
Formicinae & 3 & 3.12 & 1.84 \\
Pheidole subarmata & 2 & 2.60 & 1.82 \\
Leptothorax sp. & 2 & 1.59 & 1.13 \\
Tetramorium caldarium & 1 & 0.55 & 0.54 \\
\hline
\end{tabular}

* Percentage of ant foraging activity was estimated as explained in Materials and methods: Arthropod sampling and yield data.

vironments (Jeanne 1979). The site was characterized by a monotonous but very active ant community ( $\mathrm{Ta}$ ble 1) dominated by Pheidole radowszkoskii Mayr and Ectatomma ruidum Roger. $P$. radowszkoskii is a myrmecine with a high level of social organization and aggressive recruitment behavior (Wilson 1971). E. ruidum, on the other hand, is in the subfamily Ponerinae, which is usually considered primitive (Möglich 1973, Agbogba 1984, Jaffé 1984). Most ponerines forage as individuals, but recently the subfamily has been reported to attain a high level of the behavioral plasticity (Lachaud 1985), including cleptobiosis (I. Perfecto and J. H. Vandermeer, unpublished manuscript).

The most abundant herbivores in these fields were Spodoptera frugiperda and Dalbulus maidis. S. frugiperda occurs throughout Latin America and the southern United States, and is considered to be one of the most damaging insect pests of maize in Central America (Ortega 1974, Chiang 1977, van Huis 1981), with yield losses of 30 to $60 \%$ (van Huis 1981). Damage to maize plants consists mainly of defoliation of the whorl, but sometimes larvae tunnel into the stalk and feed on the meristematic tissue of the bud, thereby killing the plant (Burkhardt 1952). Although S. frugiperda has a wide range of hosts, its preferred host is maize. Oviposition by $S$. frugiperda occurs mainly during the whorl and tasseling stages, which results in a pattern of egg mass deposition characterized by two peaks. The average duration of the larval stage is $11.1 \mathrm{~d}$, ranging from 9.6 to $20 \mathrm{~d}$ (Estrada 1960). The average duration of the pupal stage has been reported to be $8.8 \mathrm{~d}$ (Estrada 1960) and 7.9 d (Randolph and Wagner 1966). Because S. frugiperda pupates in the soil it is particularly vulnerable to ground-foraging ants.

The corn leafhopper, D. maidis, occurs throughout Latin America and is abundant on the Pacific side of Nicaragua. Direct plant damage by this sap-sucking insect is trivial, but it is the primary vector of several important maize diseases, such as maize stunt spiroplasma and the rayado fino virus (Gámez 1969, 1980, Nault 1980, Power 1987, Vandermeer and Power 1990), the first of which is a particularly devastating problem in Nicaragua. The spiroplasma is transmitted only by leafhopper feeding, and is never seed-borne (Nault 1980). Furthermore, it appears that transmission from the leafhopper to the maize plant requires long feeding periods (hours to days; Anaya 1975), implying that predators may be able to protect maize plants from infection simply by disrupting leafhoppers that are feeding.

The system I have studied consists of maize, which is eaten by two herbivores, which are in turn eaten by ground-foraging ants. The general question is whether the desired effect of the insecticide on the herbivore population outweighs the undesired negative effect on its natural enemies.

\section{Materials AND Methods \\ Crop establishment, management, and experimental design}

Experimental plots of maize, Zea mays, were established halfway through the 1986 rainy season (10 September). This period corresponds to the second of two normal maize production seasons. The field was cleared by machete, burned, and mechanically plowed. Plots were $6.4 \times 6 \mathrm{~m}$, and maize was planted at distances of $80 \mathrm{~cm}$ between rows and $20 \mathrm{~cm}$ between plants within rows, for a total of $\approx 279$ plants per plot (which represents a seeding density of $\approx 73000$ plants/ha, the normal seeding density for the region). Plots were separated from each other by a $2-\mathrm{m}$ non-weeded area. The pre-emergence herbicide Gramoxone was applied $2 \mathrm{~d}$ after planting, and hand-weeding was conducted $20 \mathrm{~d}$ later.

The experimental treatments were arranged in a Latin-square design with four treatments and four replicates. Treatments consisted of (1) one application of the nematocide/insecticide carbofuran, (2) one application of the contact insecticide chlorpyrifos, (3) an application of both carbofuran and chlorpyrifos, and (4) a control treatment where no insecticide was applied. This design yielded a total of 16 plots on an experimental area of $948 \mathrm{~m}^{2}$.

Carbofuran is a systemic insecticide and nematocide commonly used in granulated form against chewing and sap-sucking insects, as well as against soil insects (especially Phyllophaga sp.) and soil nematodes. In this experiment it was applied directly in the planting furrow during planting time, as is the local custom. Chlorpyrifos is a broad-spectrum insecticide frequently used in maize production in Nicaragua as a contact insecticide against Spodoptera frugiperda, Dalbulus maidis, and other common insect pests. In this experiment chlorpyrifos was applied following the common practice used in small- and medium-sized farms throughout Central America. The insecticide was mixed with sawdust and then placed by hand in the whorl of each 
maize plant, using the technique commonly used by producers of the area of a standard "pinch" of the mixture, taken with the thumb and two fingers. The recommended dose of $500 \mathrm{~cm}^{3} / 0.7$ ha was used. It was applied only once, $26 \mathrm{~d}$ after planting. The treatment with the combination of both insecticides was established by applying carbofuran the same way and at the same time that it was applied in the carbofuran-only treatment and then applying chlorpyrifos the same way and at the same time that it was applied in the chlorpyrifos-only treatment. Thus, before chlorpyrifos was applied ( $26 \mathrm{~d}$ after planting), the experiment effectively consisted of a randomized block design with two replications of control of carbofuran per block. After the chlorpyrifos treatment was applied, the design became a Latin-square design with four treatments of four replicates.

\section{Arthropod sampling and yield data}

Ants were sampled by using tuna baits $(\approx 2 \times 3 \times$ $3 \mathrm{~cm}$ ) placed on the ground at four locations within each plot, each location representing the corner of a 2 $\times 2.4 \mathrm{~m}^{2}$ rectangle and separated from the border of the plot by $2 \mathrm{~m}$. Baiting as a means of sampling ants is a common procedure in myrmecological studies (Saks and Carroll 1980, Castiñeiras and Brito 1983, Savolainen and Vepsäläinen 1988). After 15 min each bait was checked, and the ant species and abundance index of each species was recorded. Because it was not possible to count accurately the number of individuals at each bait for some species, a relative index of abundance was used, where " 1 " represented between 1 and 4 individuals, " 2 " represented between 5 and 10 individuals, and " 3 " represented $\geq 11$ individuals. For the two ponerine species in the study (Ectatomma rui$d u m$ and Odontomachus sp.), exact numbers of individuals could be counted, since the swarms of these ponerines were usually small and the individuals are large.

An initial ant sampling was performed before any treatment was applied to the experimental plots. Subsequent samples were taken at intervals of 2 to $6 \mathrm{~d}$ (except for the last sample which was performed $24 \mathrm{~d}$ after the previous one), and included all of the whorl and tasseling period. An index of ant foraging activity for each plot was estimated by combining the percentage of baits occupied by ants and the abundance index for each bait. On 24 September 1986 the distance between the bait and the nest entrance of the foraging ants was recorded for 43 nests of Pheidole radowszkoskii.

On 27 and 29 September 1986 maize plants were examined for foraging ants. Fifteen plants per plot were examined, and the abundance of each ant species was noted.

Numbers of $S$. frugiperda larvae were estimated by carefully examining all leaves and the whorl of each sampling plant. No data were taken on $S$. frugiperda egg masses. The three central rows and $3 \mathrm{~m}$ within each row were divided into 9 portions of $\approx 5$ plants each, 3 of which were randomly selected during each sampling period, for a total of 15 plants sampled per plot. A total of six such censuses was taken throughout the growing season, three before and three after the application of chlorpyrifos.

I expected heavy predation on pupae because the ants are mainly ground foragers, and because $S$. frugiperda pupates in the soil. To estimate this source of predation, a total of 72 pupae of $S$. frugiperda were placed in the soil at a depth of $3 \mathrm{~cm}$. Of those 72 pupae, 24 were placed in the plots with the chlorpyrifos and carbofuran treatments (six in each plot), another 24 were placed in the control treatments (also six in each plot) and another 24 in an adjacent, traditional no-till field where no insecticide had been applied. This latter field, separated by $\approx 6 \mathrm{~m}$ from the experimental site, was planted with a mixture of maize and beans. The pupae baits were checked every day for four consecutive days, at which point most of the pupae had been removed in one of the treatments, and desiccation was beginning to occur in some of the others. Ant foraging activity also was estimated for these plots the 4th d after placing the pupae.

Estimates of Dalbulus maidis numbers were obtained by counting the number of adults sitting in the whorl of each 15 sampled plants selected in the same fashion as the samples for $S$. frugiperda. These leafhoppers spend all of their time, except when moving between plants, in the whorl (Power 1987). While they are easily disturbed at high temperatures, leafhoppers are relatively sedentary in the cooler hours of early morning. Thus all counts were taken between 0600 and 0800 in the morning, when insect activity is minimal. Three censuses were conducted for $D$. maidis, two before the application of chlorpyrifos and one after.

On 13 November 1986, $60 \mathrm{~d}$ after planting, 15 plants per plot were inspected for symptoms of corn stunt (which is transmitted by $D$. maidis); the 15 plants were selected as in the case of $S$. frugiperda and $D$. maidis sampling. To quantify the severity of the pathogen an index was used where " 1 " represented from 1 to 3 red leaves, " 2 " represented from 4 to 6 red leaves and " 3 " represented from 7 to 10 red leaves (red leaves are an indication of infection).

Although no specific sampling program was established for non-formicine predators, whenever one was encountered during herbivore sampling it was recorded.

On 10 December 1986, $90 \mathrm{~d}$ after planting, yield data were recorded. Ears from all plants in the three central rows $(\approx 15$ plants/row, or 45 plants/plot), leaving a $1.5-\mathrm{m}$ border at each end of the rows, were gathered, counted, air-dried, and weighed. 


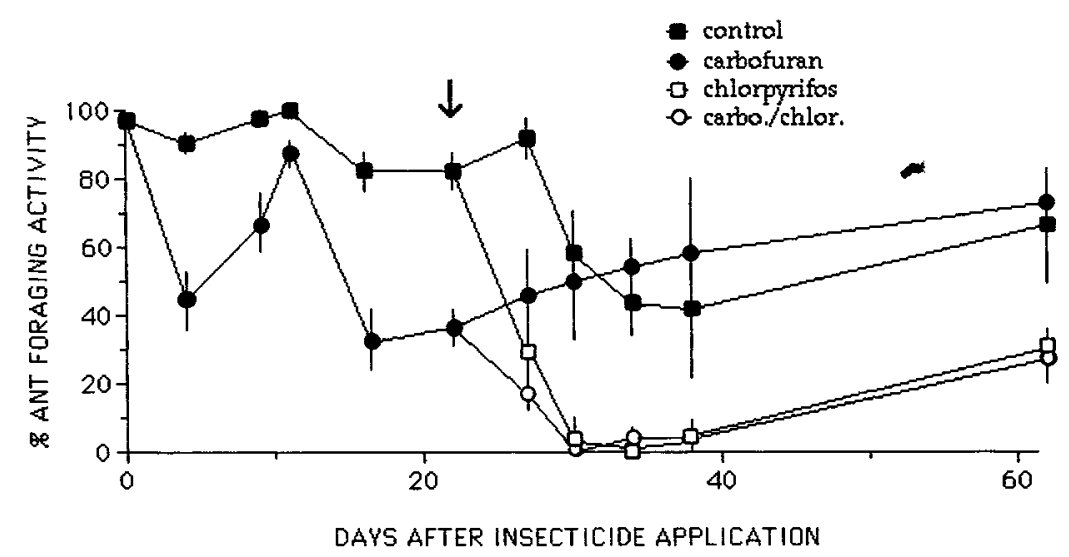

FIG. 1. Percentage of ant foraging activity for the carbofuran and the control treatments before and after the application of chlorpyrifos. The arrow represents the last sampling date before the application of chlorpyrifos, after which ant foraging activity for all four treatments is shown. Error bars denote \pm 1 SE.

\section{Statistical analysis}

Statistical analysis for ant foraging activity as well as for S. frugiperda and D. maidis was divided into two separate analyses: before and after the application of chlorpyrifos. In the analysis for data before the application of chlorpyrifos, ant foraging activity as well as numbers of $S$. frugiperda and $D$. maidis were compared within and among the two factors (with treatments being carbofuran and control) using a repeatedmeasures analysis of variance. The ANOVA model before the application of chlorpyrifos was a two-way factorial analysis: insecticide treatment $\times$ block, with two levels of insecticide (carbofuran and the control) and four blocks with two replicates of each treatment within blocks. Five trials represented the first five sampling periods for ant foraging activity, and three trials represented the first three sampling periods for $S$. frugiperda. Two samples were taken for $D$. maidis.

After chlorpyrifos was applied, the overall ANOVA was a three-way factorial analysis: insecticide treatment $\times$ row blocking variable $\times$ column blocking variable (a Latin-square design) with four levels of each factor as described earlier. The repeated-measures ANOVA included five trials for ant foraging activity and three for numbers of $S$. frugiperda. Since only one sample was obtained for $D$. maidis after the application of chlorpyrifos, repeated-measures ANOVA was not required. Within this general model, several a posteriori contrasts were performed using the Duncan's multiple range tests. All statistical analyses for ant foraging activity were done using the arcsine transformation for proportions. A Pearson's correlation coefficient was obtained between the number of pupae of $S$. frugiperda remaining in the soil and ant foraging activity. The assumptions of variance homogeneity and normality were tested for all ANOVAs using Bartlett's test and an analysis of the residuals. Variances were found to be not significantly heterogeneous $(P>.10)$, and the assumption of normality was met.
Data for symptoms of the corn stunt as well as for yield were compared within and between factors using a three-way factorial ANOVA (no interaction term was tested).

\section{RESULTS \\ Ant foraging activity}

After the application of carbofuran the ant community on the experimental site continued to be dominated by two species, Pheidole radowszkoskii and Ectatomma ruidum, although a total of 12 species were encountered throughout the season. The two predominant species were found on $>90 \%$ of the baits throughout the season. The pattern of two species predominating, one a swarming species ( $P$. radowszkoskii) and the other a larger, more individually foraging species (E. ruidum), is commonly encountered in agricultural fields in this area (Sediles 1989).

Insecticide application had a significant effect on the ants' foraging activity (Fig. 1). Before the application of chlorpyrifos, ant foraging activity was significantly higher in the control as compared to the carbofuran treatment $(P<.001)$ (Table 2). For the first five sampling dates average ant foraging activity fluctuated from 82 to $100 \%$ in the control plots, while in the plots with carbofuran it dropped from $96.9 \%$ before the insecticide was applied, to $33.5 \%$ after carbofuran application (Fig. 1). Ant foraging activity was further reduced after chlorpyrifos was applied, to the point of being virtually nonexistent (Table 3B). All reductions in ant foraging activity were significant $(P<.05)$ (Table 3A). This difference was further analyzed using a posteriori contrasts (Table 3B), which indicated that ant foraging activity was significantly higher in the carbofuran and control treatments as compared to the two treatments that received the chlorpyrifos application.

The average distance from the baits on which $P$. radowszkoskii was foraging to the entrance of its nest was $0.9 \mathrm{~m}$, with a coefficient of variation of $53 \%(N=$ 
TABLE 2. Repeated-measures analysis of variance of proportion $(p)$ of baits occupied by ants before application of chlorpyrifos. Data were transformed to arcsine $\sqrt{p}$ prior to analysis.

\begin{tabular}{lrrrrr}
\hline \hline \multicolumn{1}{c}{ Source of variation } & \multicolumn{1}{c}{ ss } & df & MS & \multicolumn{1}{c}{$F$} & $P$ \\
\hline Treatment & 29695 & 1 & 29695 & 64.209 & $\ll .001$ \\
Replication (block) & 1023 & 3 & 341 & 0.738 & .559 \\
Treatment $\times$ Replication & 367 & 3 & 122 & 0.265 & .849 \\
Error & 3700 & 8 & 462 & & \\
Total & 34785 & 15 & & & \\
\hline
\end{tabular}

43). The longest foraging distance recorded for this species was $2.3 \mathrm{~m}$.

For the two dates when the crop plants were sampled for the presence of ants, a total of 55 individual ants were recorded on a total of 120 plants in the control plots. For the same number of plants and sampling dates, only 13 ants were recorded foraging with the carbofuran treatment $(t=2.973 ; P<.01)$. The number of ants patrolling the crops in the experimental treatment was lower than that in the control by a factor of $>4$, similar to the general difference noted in groundforaging activity. As with the ground foragers, $93 \%$ of the ants foraging on the plants were either $P$. radowszkoskii $(53 \%)$ or E. ruidum $(40 \%)$.

Other predators were encountered throughout the season, but in very low numbers. For a total of five sampling periods and 240 plants per sampling period, a total of 3 spiders and 32 earwigs, Doru taeniatum (Dohrn)(Dermaptera: Forficulidae), were encountered.

\section{Spodoptera frugiperda}

The application of carbofuran increased the numbers of larvae of $S$. frugiperda (Fig. 2). Numbers of larvae were significantly higher in the carbofuran treatments than in the control $(P<.001)$ (Table 4$)$. On the subsequent dates, after chlorpyrifos was applied, the numbers of larvae of $S$. frugiperda decreased dramatically in response to the chlorpyrifos application, and those numbers were significantly lower than in the carbofuran and control treatments $(P<.001)$ (Table 5A). The difference between the carbofuran treatment and the control remained significant throughout all sampling dates $(P<.05)$ (Table 5B).

Ninety-two percent of all pupae placed in the traditional no-till field were removed within $4 \mathrm{~d}$ compared with only $4 \%$ on the experimental site with insecticide. At the same time, ant foraging activity for those same sites was $97 \%$ for the traditional field and $4.2 \%$ for the experimental site with insecticide (Fig. 3). The Pearson's correlation between the number of pupae removed and ant foraging activity was 0.92 . All of the actual sightings of pupa predation $(\approx 23 \%$ of all predation) involved ants.

\section{Dalbulus maidis}

No significant difference was found for numbers of $D$. maidis between the carbofuran treatment and the control $(P>.10)$. After the application of chlorpyrifos, however, insecticide treatments influenced numbers of leafhoppers per plant (Table 6A). The significant effect of insecticide treatment was further analyzed using an a posteriori test of multiple comparisons. Leafhopper numbers were significantly higher in the chlorpyrifos treatment as compared to all other treatments (Table 6B; Fig. 4). Despite the significant increase of $D$. maidis individuals in the chlorpyrifos treatments, no significant difference was found for symptoms of maize stunt among any of the treatments in the Latin-square design $(P>.10)$, in a survey taken on 13 November 1986 .

\section{Maize yields}

Neither numbers of ears nor mass of ears was significantly different within or between treatments $(P>$ .10). Yields were lower than normal for the region because of a severe drought toward the end of the season (Table 7).

\section{Discussion}

These results demonstrate the indirect effect that results from the application of insecticides in a maize agroecosystem in the tropics. The application of carbofuran resulted in significantly higher numbers of lar-

TABLE 3. Repeated-measures analysis of variance of proportion $(p)$ of baits occupied by ants after application of chlorpyrifos on 6 Oct. Data were transformed to arcsine $\sqrt{p}$ prior to analysis.

\begin{tabular}{lrrrcc}
\hline \hline $\begin{array}{l}\text { A) ANOVA table } \\
\begin{array}{l}\text { Source of } \\
\text { variation }\end{array}\end{array}$ & \multicolumn{1}{c}{ ss } & df & \multicolumn{1}{c}{ MS } & $F$ & $P$ \\
\hline Row block & 2608 & 3 & 869 & 0.867 & .508 \\
Column block & 2056 & 3 & 685 & 0.683 & .594 \\
Treatment & 16809 & 3 & 5603 & 5.588 & .036 \\
Error & 6016 & 6 & 1003 & & \\
Total & 27489 & 15 & & &
\end{tabular}

B) Post-hoc contrasts of the insecticide treatments. Values followed by different superscript letters are significantly different at $P<.01$ (Duncan's multiple range test).

Mean proportion of baits occupied by ants

\begin{tabular}{lccccc} 
& 8 Oct & 11 Oct & 15 Oct & 19 Oct & 12 Nov \\
\cline { 2 - 6 } & $.46^{\mathrm{a}}$ & $.50^{\mathrm{a}}$ & $.54^{\mathrm{a}}$ & $.58^{\mathrm{a}}$ & $.73^{\mathrm{a}}$ \\
Carbofuran & $.92^{\mathrm{b}}$ & $.58^{\mathrm{a}}$ & $.44^{\mathrm{a}}$ & $.42^{\mathrm{a}}$ & $.67^{\mathrm{a}}$ \\
Control & & & & & \\
$\quad$ Cyrbofuran and & $.17^{\mathrm{c}}$ & $.00^{\mathrm{b}}$ & $.04^{\mathrm{b}}$ & $.04^{\mathrm{b}}$ & $.27^{\mathrm{b}}$ \\
Chlorpyrifos & $.29^{\mathrm{c}}$ & $.04^{\mathrm{b}}$ & $.00^{\mathrm{b}}$ & $.04^{\mathrm{b}}$ & $.31^{\mathrm{b}}$ \\
\hline
\end{tabular}




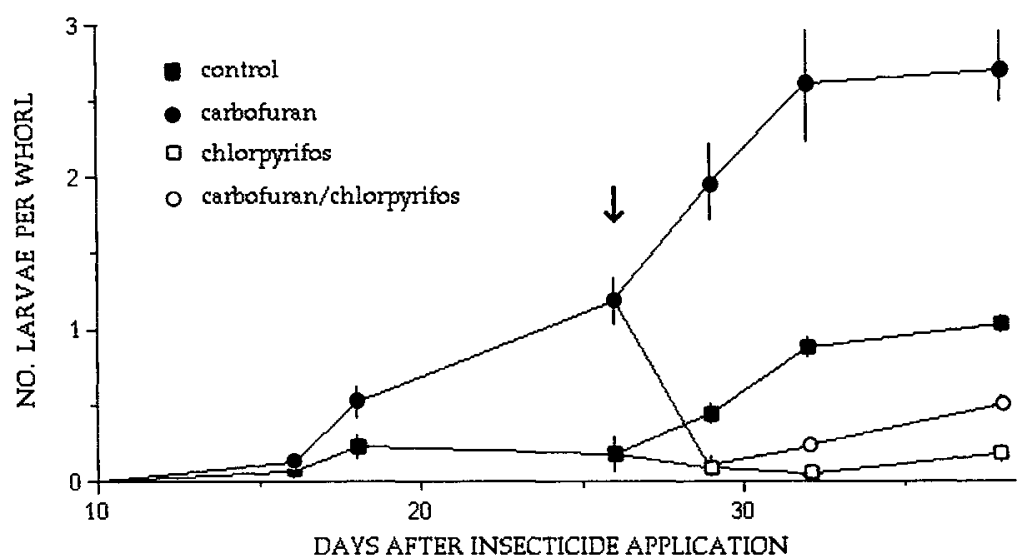

Fig. 2. Numbers of Spodoptera frugiperda per maize plant during the growing season for the carbofuran and the control treatments before and after the application of chlorpyrifos. The arrow represents the last sampling date before the application of chlorpyrifos, after which numbers of $S$. frugiperda are shown for all four treatments. Error bars denote \pm 1 SE.

vae of Spodoptera frugiperda. I speculate that this effect is an indirect one attained through a dramatic reduction of predatory ants (Fig. 5). After the application of this systemic insecticide (in a granulated form), several ants were observed carrying granules of the chemical to their nests. Ant colonies closer to the planting furrow (where the insecticide was applied) may have died, therefore decreasing ant foraging activities in the plots. No nest movement was observed, suggesting that reduction in foraging activity was not the result of massive emigrations from treated plots, but rather the elimination of colonies within plots. The hypothesis that insecticide application has an indirect effect on pest populations through the reduction or elimination of ant foraging activity, and that this indirect effect can be detected in a single growing season, is further supported by the results of the pupa experiments. In areas not affected by insecticide application (the adjacent traditional field), almost $100 \%$ of the baits were occupied by ants, and at the same time $>90 \%$ of experimentally deployed pupae were removed from the ground after $4 \mathrm{~d}$. It was common to observe individuals of Ectatomma ruidum or swarms of Pheidole radowszkoskii preying upon the pupae.

Application of chlorpyrifos significantly depressed S. frugiperda abundance and significantly increased leafhopper abundance. The increase in leafhoppers after chlorpyrifos application is probably due to a gen-

TABLE 4. Repeated-measures analysis of variance of number of Spodoptera frugiperda per plant before application of chlorpyrifos.

\begin{tabular}{lccccc}
\hline \hline Source of variation & ss & df & Ms & $F$ & $P$ \\
\hline Treatment & 2.55 & 1 & 2.55 & 34.622 & $\ll .001$ \\
Replication (block) & 0.02 & 3 & 0.01 & 0.082 & .968 \\
Treatment $\times$ & & & & & \\
$\quad$ Replication & 0.03 & 3 & 0.01 & 0.116 & .948 \\
Error & 0.59 & 8 & 0.07 & & \\
Total & 3.19 & 15 & & & \\
\hline
\end{tabular}

erally negative correlation between $S$. frugiperda and Dalbulus maidis and the fact that this insecticide did kill $S$. frugiperda. The leafhoppers appear to prefer plants that have the least $S$. frugiperda damage.

The observation that carbofuran had no effect on maize pests is surprising, since this insecticide is still highly recommended in Nicaragua as an effective control against $S$. frugiperda and $D$. maidis (Anaya and Diaz 1974, and personal conversations with Nicaraguan peasant farmers, 1987). However, in no way is this result unique (Sterling et al. 1984). A review of pesticide impacts on ecosystems by Pimentel and Edwards (1982) concluded, among other things, that predators and parasites were more likely to be severely affected than species at lower levels of the lower food web (i.e., herbivores). The negative effect of insecticides as a result of their effect on natural enemies has

TABLE 5. Repeated-measures analysis of variance of number of Spodoptera frugiperda per plant after application of chlorpyrifos.

\begin{tabular}{lrrrrc}
\hline \hline $\begin{array}{l}\text { A) ANOVA table } \\
\begin{array}{l}\text { Source of } \\
\text { variation }\end{array}\end{array}$ & \multicolumn{1}{c}{ ss } & df & \multicolumn{1}{c}{ MS } & \multicolumn{1}{c}{$F$} & $P$ \\
\hline Row block & 1.15 & 3 & 0.38 & 1.027 & .445 \\
Column block & 1.75 & 3 & 0.58 & 1.561 & .294 \\
Treatment & 40.04 & 3 & 13.35 & 35.683 & $\ll .001$ \\
Error & 2.24 & 6 & 0.37 & & \\
Total & 45.19 & 15 & & &
\end{tabular}

B) Post-hoc contrasts of the insecticide treatments. Values followed by different superscript letters are significantly different at $P<.05$ (Duncan's multiple range test).

\begin{tabular}{llll} 
& \multicolumn{3}{l}{ Mean number of larvae per plant } \\
\cline { 2 - 4 } & 10 Oct & 13 Oct & 19 Oct \\
\hline Carbofuran & $1.950^{\mathrm{a}}$ & $2.617^{\mathrm{a}}$ & $2.700^{\mathrm{a}}$ \\
Control & $0.450^{\mathrm{b}}$ & $0.883^{\mathrm{b}}$ & $1.033^{\mathrm{b}}$ \\
Carbofuran and & & & \\
$\quad$ Chlorpyrifos & $0.117^{\mathrm{b}}$ & $0.023^{\mathrm{c}}$ & $0.516^{\mathrm{c}}$ \\
Chlorpyrifos & $0.083^{\mathrm{b}}$ & $0.050^{\mathrm{c}}$ & $0.183^{\mathrm{c}}$ \\
\hline
\end{tabular}




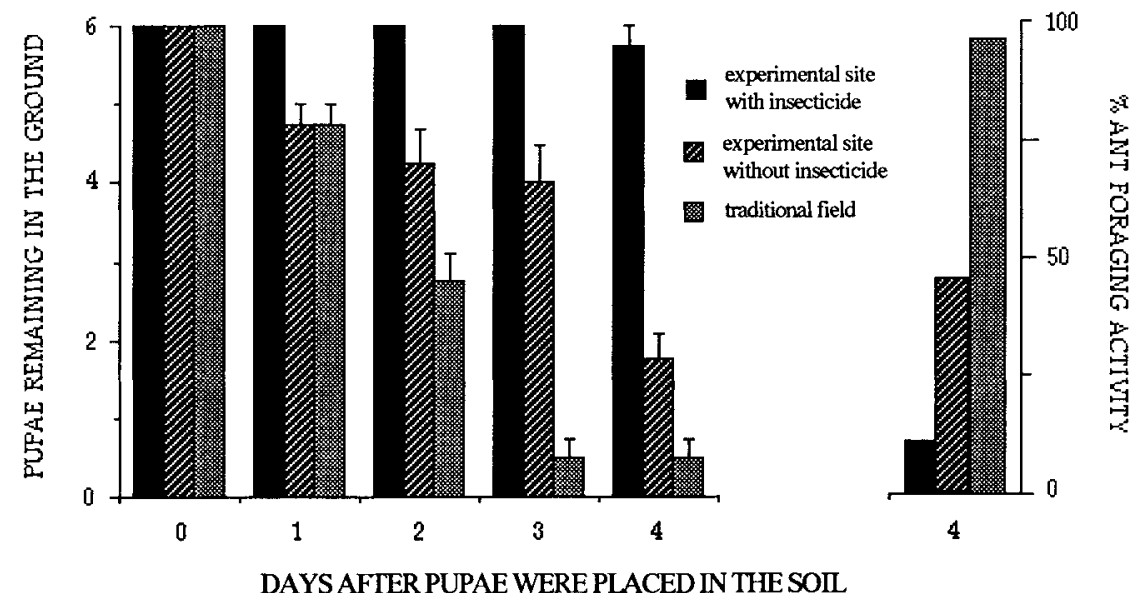

FIG. 3. Average number of pupae of Spodoptera frugiperda remaining in the soil $0,1,2,3$, and $4 \mathrm{~d}$ after they were placed in: (a) insecticide plots within the experimental site, (b) control plots within the experimental site, and (c) an adjacent traditional no-till field (where no insecticide had been applied) outside the experimental site ( 6 pupae $\times 4$ plots $\times 3$ treatments $=72$ pupae total). On the right is the percentage of ant foraging activity during the fourth day for each treatment. Error bars denote $+1 \mathrm{SE}$.

been reported previously (Franz et al. 1980, Roach and Hopkins 1981, Sterling et al. 1984). The reason given, in most cases, is the lack of selectivity of the chemical insecticide and the inability of the enemy populations to recuperate as fast as their prey (Smith and van den Bosch 1967, Pimentel and Edwards 1982). In this study, however, a "selective" insecticide ("selective" because it is a systemic) had the same negative effect on predatory ants as one would expect from a wide-spectrum insecticide.

The ineffectiveness of carbofuran as a control measure for the two main maize pests is probably due to the evolution of resistance. Although resistance of these two pests to carbofuran has not been reported in the recent literature, the intensive use of this insecticide for the last 15 yr makes it a very likely hypothesis.

TABLE 6. Analysis of variance of the number of leafhoppers per plant.

\begin{tabular}{lcrccc}
\hline \hline $\begin{array}{l}\text { A) ANOVA table } \\
\begin{array}{l}\text { Source of } \\
\text { variation }\end{array}\end{array}$ & ss & df & Ms & \multicolumn{1}{c}{$F$} & $P$ \\
\hline Row block & 0.21 & 3 & 0.07 & 1.286 & .362 \\
Column block & 0.43 & 3 & 1.14 & 2.623 & .145 \\
Treatment & 2.21 & 3 & 0.74 & 13.529 & .004 \\
Error & 0.33 & 6 & 0.05 & & \\
Total & 3.17 & 15 & & &
\end{tabular}

B) Post-hoc contrasts of the various insecticide treatments. Values followed by different superscript letters are significantly different at $P \leq .001$ (Duncan's multiple range test).

Number of leafhoppers per plant

\begin{tabular}{lc}
\hline Chlorpyrifos & $2.967^{\mathrm{a}}$ \\
Carbofuran & $2.300^{\mathrm{b}}$ \\
Carbofuran and Chlorpyrifos & $2.000^{\mathrm{b}}$ \\
Control & $2.048^{\mathrm{b}}$ \\
\hline
\end{tabular}

In contrast to their effects on herbivorous pests, both carbofuran and chlorpyrifos had a strong negative effect on ant foraging activity. This strong effect is not surprising because resistance among predators is unusual (Croft and Brown 1975), and ants are reported to be especially susceptible to insecticides (Schread 1948, Gerhardt 1954, Lofgren et al. 1964, Beaston 1968, Su et al. 1980, Castiñeiras et al. 1985). Ants were especially susceptible to chlorpyrifos. Just one applica-
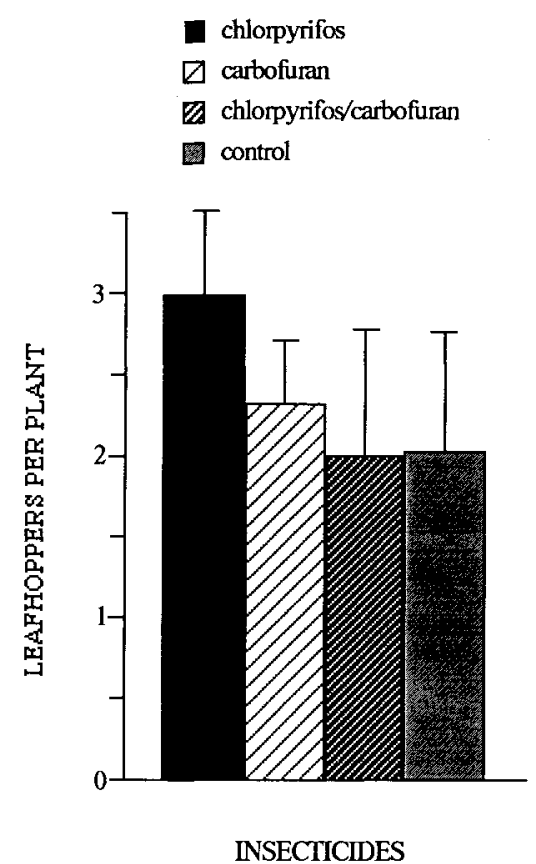

Fig. 4. Number of Dalbulus maidis per maize plant at four levels of insecticide: chlorpyrifos, carbofuran chlorpyrifos with carbofuran, and a control (with no insecticide). Error bars denote $+1 \mathrm{SE}$. 
TABle 7. Numbers and mass of corn ears $(\bar{X} \pm 1 \mathrm{SE})$ per $45-$ sample plants per plot $(n=4)$.

\begin{tabular}{lccc}
\hline \hline $\begin{array}{c}\text { Insecticide } \\
\text { treatment }\end{array}$ & $\begin{array}{c}\text { Number } \\
\text { of ears }\end{array}$ & $\begin{array}{c}\text { Mass } \\
(\mathrm{kg} / 45 \text { plants })\end{array}$ & $\begin{array}{c}\text { Extrap- } \\
\text { olated } \\
\text { mass } \\
(\mathrm{kg} / \mathrm{ha})\end{array}$ \\
\hline Carbofuran & $44.75 \pm 9.99$ & $1.44 \pm 0.31$ & 1641.69 \\
Chlorpyrifos & $38.50 \pm 11.58$ & $1.01 \pm 0.34$ & 2210.28 \\
Carbofuran/ & & & \\
$\quad$ Chlorpyrifos & $42.50 \pm 5.63$ & $1.36 \pm 0.23$ & 2696.13 \\
Control & $55.00 \pm 4.14$ & $1.66 \pm 0.05$ & 2336.00 \\
\hline
\end{tabular}

tion of this insecticide, applied as a mixture with sawdust directly in the whorl of the maize, was enough to reduce ant foraging activity to negligible levels. The day after application of chlorpyrifos many ants were found dead in the maize whorls and in the soil. Indeed, the effect of this insecticide on ants was so strong that it seemed to affect the controls, perhaps by drift (Fig. 1), suggesting that the distance between plots should have been greater. The possibility of a strong drifting effect exhibited by chlorpyrifos should be more closely examined, given the intensive use of this insecticide in Nicaragua. The effect of "drift-level" low dosages of insecticide on maize agroecosystems has been investigated in the temperate zone (Risch et al. 1986), and there is some evidence that such low doses of carbaryl might have an important but unexpected effect on arthropod populations. As Risch et al. (1986) pointed out, the effect of insecticide drift will be most important in areas dominated by small farmers, like most Central American countries, and therefore a detailed study of drifting effects should be undertaken.

The strong negative effect of insecticides on ant foraging is very important if the natural ant community is to be used as part of an integrated pest management program. The use of ants as biological control agents of insects has a long history. Ants have been used for hundreds of years in Yemen to control date palm pests (Clausen 1940), and in China to control citrus pests (Groff and Howard 1924), and have been found to be effective biological control agents in temperate forests and perennial crops (Dmitrienko 1964, Dobrecheu 1964, Smirnov 1964, Adlung 1966, Ceballos 1970, Leston 1973, Room 1973, De Bach 1974, Finnegan 1975, Kim and Marakami 1980, Laine and Niemela 1980, Majer 1982, Torres 1982). Some studies in the temperate and subtropical zones of the U.S. emphasize their role as natural control agents in cotton (Jones and Sterling 1979, Sterling et al. 1984, Fillman and Sterling 1985), soybean (Whitcomb et al. 1972), and sugar cane (Reagan et al. 1972). However, there is limited information about their role in annual cropping systems in the tropics (but see Saks and Carroll 1980, Risch 1981, Risch and Carroll 1982a, b). Important exceptions include the work of Castiñeiras et al. (1982) in Cuba where Pheidole megacephala Fabricius is effectively

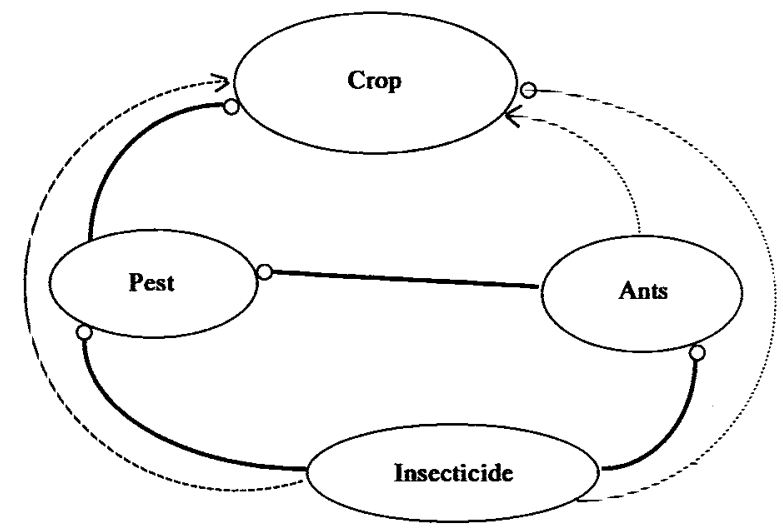

Fig. 5. Diagram of system interactions. Solid lines denote direct effects and dotted lines denote indirect ones; small open circles denote negative effects and arrows denote positive ones.

used to control Cylas formicarius Fabricius (Coleoptera: Curculionidae) in sweet potatoes.

The combination of carbofuran and chlorpyrifos, applied in the manner recommended in Nicaragua, effectively controls $S$. frugiperda, yet does not result in an increase in leafhopper densities as does chlorpyrifos alone. However, the consequent reduction in yield loss is trivial when set against the economic cost of the insecticides and their application. The controls in the present study had only the native ant fauna, and maize yields in these plots were not significantly different from those where insecticide was applied. It is important to point out that if the comparison were to be made between application and no application of insecticide in an area devoid of ants (i.e., because the ants had been eliminated by insecticide applications in the previous season), the pesticides would probably appear to be economically advisable.

\section{ACKNOWLEDGMENTS}

Gary Fowler, Peter Kareiva, John Vandermeer, Herb Wagner, John Witter, Don Zak, and two anonymous reviewers provided helpful comments that improved the quality of this manuscript. The Instituto Superior de Ciencias Agropecuarias (ISCA) in Managua, Nicaragua, provided logistic support. William Gamboa, Alberto Sediles, Nestor Bonilla, Mauricio Rodriguez, and Emilio Pérez helped in different aspects of the study. This study was undertaken as part of a dissertation in partial fulfillment for the requirements for a Ph.D. degree at the University of Michigan. Funds were provided by the Fulbright Collaboration Program (with Dr. Brian Shultz), the King/Chávez/Parks Fellowship of the State of Michigan, the School of Natural Resources of the University of Michigan, and the Horace Rackham Graduate School of the University of Michigan.

\section{Literature Cited}

Adlung, K. G. 1966. A critical evaluation of the European research on the red wood ants (Formica rufa Group) for the protection of forests against harmful insects. Zeitschrift für Angewandte Entomologie 57:167-189.

Agbogba, C. 1984. Observations sur le comportement de marche en tandem chez deux espéces de Fourmis Ponérines: 
Mesaponera caffraria (Smith) et Hypoponera sp. (Hym:Formicidae). Insectes Sociaux, Paris 31:264-276.

Anaya, M. A. 1975. Determinación del periodo mínimo y óptimo de inoculación necesario para que el vector $\mathrm{Dal}$ bulus maidis transmita el patógeno causante del achaparramiento del maíz. SIADES (El Salvador) 4:9-14.

Anaya, M. A., and A. Diaz. 1974. Determinación del effecto de Furadan 5\%G. y Dysiton 5\%G en el control del vector del achaparramiento en maiz. SIADES (El Salvador) 3:110 115.

Beaston, S. 1968. Eradication of pharaoh ants and crickets using Chlodecone baits. Integrated Pest Control 10:8-10.

Burkhardt, C. C. 1952 . Feeding and pupating habits of the fall armyworm in corn. Journal of Economic Entomology 45:1035-1037.

Castiñeiras, A., and A. Brito. 1983. Comportamiento de Pheidole megacephala (Hymenoptera:Formicidae) ante diferentes tipos de cebos. Ciencia Tecnologia y Agricultura 6:63-70.

Castiñeiras, A., S. Caballero, G. Rego, and M. González. 1982. Efectividad técnica-económica del empleo de la hormiga leona Pheidole megacephala en el control del tetuán del boniato Cylas formicarius elegantulus. Ciencia Tecnologia y Agricultura. Suplemento diciembre 103-109.

Castiñeiras, A., O. Obregón, and A. Borges. 1985. Persistencia de la actividad biológica de siete insecticidas químicos sobre Pheidole megacephala, en condiciones de laboratorio. Ciencia Tecnologia y Agricultura 8:29-43.

Ceballos, P. 1970. Las hormigas rojas y su utilidad contra las plagas forestales. Hojas Divulgadoras. Publicación de Capacitación Agrícola del Ministerio de Agricultura, Madrid 12:16-20.

Chiang, H. C. 1977. Integrated control of maize insects in Latin America. Working paper. Seventh Session of the Panel of Experts on Integrated Pest Control. AGP:IPC/WP/9. Food and Agriculture Organization of the United Nations. Rome, Italy.

Clausen, C. P. 1940. Entomophagous insects. McGraw Hill, New York, New York, USA.

Croft, B. A., and A. W. A. Brown. 1975. Responses to arthropod natural enemies to insecticides. Annual Review of Entomology 20:285-335.

De Bach, P. 1974. Biological control by natural enemies. Cambridge University Press, Cambridge, England.

Dmitrienko, U. K. 1964. Distribution of ants according to forest types in pine forest of the southwestern basin of the Angara River. Pages 112-114 in A. I. Cherepanov, editor. Biological control of agricultural and forest pests. IPST Press, Jerusalem, Israel.

Dobrecheu, U. F. 1964. Species composition of ants and their correlation with foci or leaf-mining pests in the Urals Experimental Training Forest Farm. Pages 114-115 in A. I. Cherepanov, editor. Biological control of agricultural and forest pests. IPST Press, Jerusalem, Israel.

Estrada, F. A. 1960. Lista preliminar de insectos asociados al maiz en Nicaragua. Turrialba 10:68-73

Fillman, D. A., and W. L. Sterling. 1985. Inaction levels for the red imported fire ant, Solenopsis invicta (Hym.: Formicidae): a predator of the boll weevil Anthonomus grandis (Col.: Curculionidae). Agriculture Ecosystems and Environment 13:93-102.

Finnegan, R. J. 1975. Introduction of a predaceous redwood ant, Formica lugubris (Hymenoptera:Formicidae), from Italy to Eastern Canada. Canadian Entomology 107:12711274.

Franz, J. M., H. Bogenschutz, S. A. Hassan, P. Huang, E. Waton, H. Suter, and G. Gigiani. 1980. Results of a joint pesticide test program by the working group: pesticides and beneficial arthropods. Entomophaga 25:231-236.
Gámez, R. 1969. A new leafhopper-born virus of corn in Central America. Plant Diseases Reporter 53:929-932.

- 1980. Rayado fino virus disease of maize in American tropics. Tropical Pest Management 26:26-33.

Gerhardt, P. D. 1954. Argentine ant control with sprays and baits in two California lemon groves. Journal of Economic Entomology 47:591-593.

Groff, G. W., and C. W. Howard. 1924. The cultured citrus ant of south China. Lingnan Agricultural Review 2:108114.

Huffaker, C. B. 1971. Biological control. Plenum Press, New York, New York, USA.

Jaffe, K. 1984. Negentropy and the evolution of chemical recruitments in ants. Journal of Theoretical Biology 106: 587-604.

Jeanne, R. L. 1979. A latitudinal gradient in rates of ant predation. Ecology 60:1211-1224.

Jones, D., and W. L. Sterling. 1979. Manipulation of the red imported fire ants in a trap crop for boll weevil suppression. Environmental Entomology 8:1073-1077.

Kim, C. H., and Y. Marakami. 1980. Ecological studies on Formica yessensis Forel, with special reference to its effectiveness as a biological control agent of the pine caterpillar moth in Korea. Journal of the Faculty of Agricuture, Kyushu University 25:113-119.

Lachaud, J. P. 1985. Recruitment by selective activation: an archaic type of mass recruitment in a ponerine ant (ECtatomma ruidum). Sociobiology 11:133-142.

Laine, K. J., and P. Niemela. 1980. The influence of ants on the survival of mountain birches during an Oporina autumnata (Lepidoptera: Geometridae) outbreak. Oecologia (Berlin) 47:39-42.

Leston, D. 1973. The ant-mozaic-tropical tree crops and the limiting of pests and diseases. PAN 19:311-341.

Levins, R. 1975. Evolution in communities near equilibrium. Pages 16-50 in M. L. Cody and J. M. Diamond, editors. Ecology and evolution of communities. Harvard University Press, Cambridge, Massachusetts, USA.

Lofgren, C. S., V. E. Alder, W. A. Panks, and N. Pierce. 1964. Control of imported fire ants with chlordane. Journal of Economic Entomology 57:331-333.

Majer, J. D. 1982. Ant manipulation in agro and forest ecosystems. Pages 166-188 in M. D. Breed, C. D. Michener, and $H$. E. Evans, editors. The biology of social insects. Westview, Boulder, Colorado, USA.

Miller, T. E., and W. C. Kerfoot. 1987. Redefining indirect effects. Pages 33-37 in W. C. Kerfoot and A. Sih, editors. Predation: direct and indirect impacts on aquatic communities. University Press of New England, Hanover, New Hampshire, USA

Möglich, M. 1973. Communication during nest moving in ants. Pages 274-279 in Proceedings of the 7th International Congress of the IUSSI. International Union for the Study of Social Insects, London, England.

Nault, L. R. 1980. Maize bushy stunt and corn stunt: a comparison of diseases symptoms, pathogen host ranges, and vectors. Phytopathology 70:659-662.

Ortega, A. 1974. Maize diseases and insects. Pages 1-41 in Proceedings, worldwide maize improvement in the 70's and the role for CIMMYT Volume 7. Centro Internacional de Mejoramiento de Maiz y Trigo, El Batán, México.

Pianka, E. R. 1987. The subtlety, complexity and importance of population interactions when more than two species are involved. Revista Chilena de Historia Natural 60:351361.

Pimentel, D., and C. A. Edwards. 1982. Pesticides and ecosystems. BioScience 32:595-600.

Power, A. G. 1987. Plant community diversity, herbivore movement and an insect-transmitted disease of maize. Ecology 68:1658-1669. 
Randolph, M. M., and P. M. Wagner. 1966. Biology and control of the fall armyworm. Texas Agricultural Experimental Station Progress Report 2431.

Reagan, T. E., G. Coburn, and S. D. Hensley. 1972. Effects of mirex on arthropod fauna in a Louisiana sugarcane field. Environmental Entomology 1:588-591.

Ripper, W. E. 1956. Effects of pesticides on the balance of arthropod populations. Annual Review of Entomology 1: 403-438.

Risch, S. J. 1981. Ants as important predators of rootworm eggs in the neotropics. Journal of Economic Entomology 74:88-90.

Risch, S. J., and C. R. Carroll. 1982a. Effect of a keystone predaceous ant, Solenopsis geminata in a non-equilibrium community. Ecology 63:1979-1983.

Risch, S. J., and C. R. Carroll. 1982b. The ecological role of ants in two Mexican agroecosystems. Oecologia (Berlin) 55:114-119.

Risch, S. J., D. Pimentel, and H. Grover. 1986. Corn monocultures versus old field: effects of low levels of insecticides. Ecology 67:505-515.

Roach, S. H., and A. Hopkins. 1981. Reduction of arthropod predator populations in cotton fields treated with insecticides for Heliothis spp. Journal of Economic Entomology 74:454-458.

Room, P. M. 1973. Control by ants of pest situations in tropical tree crops: a strategy for research and development. Papua New Guinea Agricultural Journal 24:98-103.

Saks, M. E., and C. R. Carroll. 1980. Ant foraging activity in tropical agro-ecosystems. Agro-ecosystems 6:177-188.

Savolainen, R., and K. Vepsäläinen. 1988. A competition hierarchy among boreal ants: impact on resource partitioning and community structure. Oikos 51:135-155.

Schread, J. C. 1948. Control of sail insects. Journal of Economic Entomology 41:314-318.

Sediles, A. 1989. Impacto de diferentes manejos del cultivo de maiz sobre la abundancia de la hormiga brava (Solenopsis geminata). Agroecología Neotropical 1:35-36.

Shaffer, W. M. 1981. Ecological abstraction: the consequences of reduced dimensionality in ecological models. Ecological Monographs 51:383-401.

Smirnov, B. A. 1964 . Utilization of ants in the protection of forests. Pages 152-154 in A. I. Cherepanov, editor. Biological control of agricultural and forest pest. IPST Press, Jerusalem, Israel.

Smith, R. F., and R. van den Bosch. 1967. Integrated control. Pages 295-340 in W. W. Kilgore and R. Doutt, editors. Academic Press, New York, New York, USA.
Sterling, W. L., D. A. Dean, D. A. Fillman, and D. Jones. 1984. Naturally-occurring biological control of the boll weevil (Coleoptera: Curculionidae). Entomophaga 29:1-9.

Stern, V. M., R. F. Smith, R. van den Bosch, and K. S. Hagens. 1959. The integrated control concept. Hilgardia 29:81101.

Su, T. H., J. W. Beardsley, and F. L. McEwen. 1980. AC217,300 , a promising new insecticide for use in baits for control of the bigheaded ant in pineapple. Journal of Economic Entomology 73:755-756.

Swezey, S. L., and R. Daxl. 1983. Breaking the circle of poison: the IPM revolution in Nicaragua. Food First Research Report. Institute for Food and Development Policy, San Francisco, California, USA.

Theiling, K. M., and B. A. Croft. 1988. Pesticide side-effects on arthropod natural enemies: a data-based summary. Agriculture, Ecosystems and Environment 21:191-218.

Torres, J. A. 1982. Biological control and possible use of ants in biological control of insects. Science-Ciencia 9:3944.

van den Bosch, R., and V. M. Stern. 1962. The integration of chemical and biological control of arthropod pests. Annual Review of Entomology 7:367-386.

van Huis, A. 1981. Integrated pest management in small farmer's maize crop in Nicaragua. Mededelingen Landbouwhogeschool Wageningen 81-6.

Vandermeer, J. H. 1980. Indirect mutualism: variation on a theme by Stephen Levine. American Naturalist 116:441448.

Vandermeer, J. H., B. Hazlett, and B. Rathcke. 1985. Indirect facilitation and mutualism. Pages 326-343 in D. H. Boucher, editor. The biology of mutualism. Oxford University Press, New York, New York, USA.

Vandermeer, J. H., and A. G. Power. 1990. Epidemiology of the corn stunt system in Central America: the basic model and some prospects for cultural control. Ecological Modeling, in press.

Whitcomb, W. H., H. A. Denmark, A. P. Bhatkar, and G. L. Green. 1972. Preliminary studies on the ants in Florida soybean fields. Florida Entomology 55:129-142.

Wilson, E. O. 1971. Insect societies. Harvard University Press, Cambridge, Massachusetts, USA.

Yodzis, P. 1988. The interdeterminancy of ecological interactions as perceived through perturbation experiments. Ecology 69:508-515. 